\title{
INFLUENCE OF MULTIENZYME PREPARATIONS ON PRODUCTION RESULTS AND ON SELECTED BIOCHEMICAL INDICATORS IN THE BLOOD OF PIGS FROM 10 TO 24 KG BODY MASS
}

\author{
N. VRANEŠIĆ, V. RUPIC**, LINA BAČAR-HUSKIĆ, S. BOGDAN, MIROSLAVA DOMINIS-KRAMARIĆ \\ *Faculty of Agriculture, University of Zagreb, and PLIVA Research Institute, Zagreb, Croatia
}

Received May 19, 1995

\begin{abstract}
Vranešić N., L. Rupić, V. Bačar-Huskić, S. Bogdan, M. Dominis-Kramarić: Influence of Multienzyme Preparations on Production Results and on Selected Biochemical Indicators in the Blood of Pigs from 10 to $24 \mathrm{~kg}$ Body Mass. Acta vet. Brno 1995, 64: 235-242.

Nutritional effects of two multienzyme preparations (PLIVA and Kemzyme) on the production and selected biochemical parameters in the blood of pigs weighing between 9.8 and $24 \mathrm{~kg}$ were studied during a period of 28 days. Yorkshire and Swedish Landrace crossbreds of $9.8 \mathrm{~kg}$ starting body mass were used. A total of 54 pigs were divided in three groups, a control (C) and two trial $\left(T_{1}\right.$ and $T_{2}$ ) groups with 18 pigs ( 9 males and 9 females) in each. They were fed the same starter diet. The control group received no enzyme supplement while the first group $\left(T_{1}\right)$ received the multienzyme preparation made by PLIVA and the second group $\left(T_{2}\right)$ was given a multienzyme preparation, Kemzyme (Kemin, Iowa, USA). Both diets $\left(\mathrm{T}_{1}\right.$ and $\mathrm{T}_{2}$ ) contained $0.1 \%$ of the multienzyme preparations. Pigs were kept in boxes and offered water and feed ad libitum. Nutritional parameters were measured at the end of the trial (after 28 days), while blood plasma biochemical parameters were ascertained on days 1, 14 and 28. Pigs in the control group (C) and in both trial groups $\left(T_{1}\right.$ and $\left.T_{2}\right)$ reached comparable average daily gains and average finishing body mass within the 28 days under study. The control group (C) consumed $10.9 \%$ more feed than the group $\mathrm{T}_{1}$ (PLIVA multienzyme preparation), and $4.53 \%$ more feed than the group $\mathrm{T}_{2}$ (Kemzyme) during the 28 trial days. Both experimental groups fed diets enriched with multienzyme additives PLIVA or Kemzyme, had better food conversion than the control (C) group. No adverse effects of multienzyme preparations by PLIVA or Kemzyme on health status of pigs was found as indicated by biochemical analyses. Neither death nor sickness occurred during the trial.
\end{abstract}

Nutrition, blood plasma, protein, lipid, glucose, AST, ALT, enzyme additives

Although research of the effect of different enzyme additions to the feed of domestic animals started in the 1960's, many questions have not been answered and many problems have not been solved yet. Enzymes used in animal feed are mostly of bacterial (genus Bacillus) or fungal (genuses Aspergillus, Trichoderma, Penicillium) origin (Inborr 1989). Although enzymes are of various origin, molecular weight and amino acid sequences, they have similar effects on the digestive tract of animals. Enzyme activities depend on environmental conditions such as $\mathrm{pH}$, temperature, activating substrate, inhibitors, and other factors that induce chemical reactions in the digestive tract. The effect of the addition of enzymes to animal feed is tightly connected to the species and age of animal, to the meal composition, and to the kind and number of enzymes in certain enzyme preparation. Trial results confirmed that the nutritive effect of enzymatic preparations is greater in young animals in which the entire enzyme system of digestive tract is not fully in function yet, especially when the fodder containing large portions of vegetable origin of smaller nutritive value is fed.

In young pigs the enzymatic system is not fully developed, so that feeding the weaned piglets weighing about $10 \mathrm{~kg}$ with powdered food often results in reduced gain and onset of diarrhoea (Dierick 1989). The addition of enzymes to the feed increases the utilization of nutritive substances in digestive tract of pigs and induces the disintegration of various toxins 
so that the health condition of pigs improves, gain becomes faster and food conversion more favourable (Vinovrški 1990).

Experiments confirmed that the preparations containing several various enzymes are more effective than those with only one enzyme when feeding the pigs of about $9.8 \mathrm{~kg}$ body mass. Weaned piglets can utilize all nutritive ingredients to the maximum only after all digestive enzymes have become fully effective in the small intestine. In trials with multienzyme preparation Kemzyme weaned piglets showed a $6.63 \%$ better food conversion than pigs fed with no enzymes added (Adams 1989). In young pigs with insufficiently developed digestive enzyme system, additional amylolytic, proteolytic and lipolytic enzymes have favourable effects.

Multienzyme preparations show a favourable effect when added to the diets based on barley, oats and rye (Cromwel et al. 1988; Rotter et al. 1990); in such mixes beta-glucanase is especially effective (Adams 1989; Graham et al. 1989). Another series of trials confirmed that the protease added to the feed of weaned pigs yielded considerable gain increase and better food conversion (Matošić-Čajavec et al.1989,1991).

The aim of this experiment was to study and compare the nutritive effect of two multienzyme preparations, one made by PLIVA and a U.S. made product Kemzyme on the growth rates and health state of weaned piglets.

\section{Materials and Methods}

Animals and diets

A total of 54 Yorkshire and Swedish Landrace crossbreds, divided in three groups, a control (C) and two trial groups $\left(\mathrm{T}_{1}\right.$ and $\mathrm{T}_{2}$ ), with 18 pigs in each, were used in the experiment. Pigs were kept in boxes, 9 pigs per box (a total of 6 boxes). There were 9 males and 9 females in each group, and trial groups contained pigs from 9 litters born on the same day.

Equal numbers of pigs from one litter (one male and one female) were included in each experimental group. Average starting body mass of pigs in all the groups was $9.8 \mathrm{~kg}$. All groups were kept in the same microclimatic conditions. During the 28-day period the average air temperature was $19.13^{\circ} \mathrm{C}$, and relative humidity $72.21 \%$. The animal room had a forced air circulation. Health state of the piglets was checked daily. No sickness or death were diagnosed during the experimental period.

Table 1

Composition of starter mix used in the trial

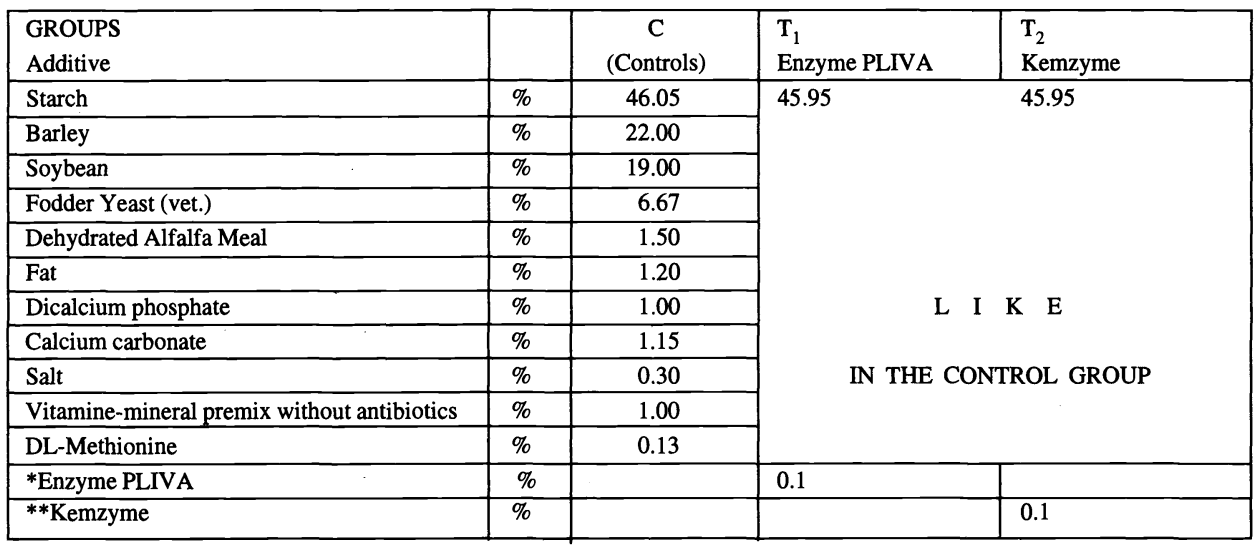

*Multienzyme preparation PLIVA contains alpha amylase, alkaline proteinase, beta glucanase. Alpha amylase and alkaline proteinase are obtained from selected strains of Bacillus sp., and beta glucanase from Aspergillus niger.

**Multienzyme preparation Kemzyme dry (KEMIN IND., Iowa, USA) contains amylase, beta glucanase, cellullase, protease, lipase. According to the producer's declaration, the activities of particular components of the multienzymatic preparation PLIVA are as follows: beta glucanase $10 \mathrm{FGU} / \mathrm{g}$, alpha amylase $10 \mathrm{XU} / \mathrm{g}$, alkaline proteinase $40 \mathrm{kDU} / \mathrm{g}$. 
Table 2

Nutritive values and chemical composition of starter mix used in the trial

\begin{tabular}{|l|l|r|}
\hline Crude protein & g.kg-1 & 185.9 \\
\hline Crude fat & g.kg & 74.4 \\
\hline Crude fibre & g.kg-1 & 34.8 \\
\hline ME & MJ/kg & 13.29 \\
\hline Lysine & g.kg-1 & 10.3 \\
\hline Methionine & g.kg-1 & 4.3 \\
\hline Ca & g.kg & 7.6 \\
\hline P & g.kg-1 & 6.4 \\
\hline
\end{tabular}

Pigs were offered the diets and water ad libitum by means of automatic feeding and watering systems. All three groups were given the same basic starter diet. The trial group $\mathrm{T}_{1}$ received a multienzyme preparation made by PLIVA, the second group $\left(\mathrm{T}_{2}\right)$ the multienzyme preparation Kemzyme (KEMIN IND., Iowa, USA). Both enzyme preparations were added at $0.1 \%$. Both were pulverized, and prepared so as not to attract moisture and become lumpy. The composition of starter diet mix is shown in Table 1, the nutritive values and chemical composition of experimental diet mixes are given in Table 2.

Body mass, feed utilization, and food conversion were determined in all groups after 28 days of the feeding period.

For biochemical analyses, blood samples were taken three times during the trial: on days 1,14 , and 28 at the same time of day $(8.00$ to $10.00 \mathrm{~h})$ from the same animals, and in the same group sequence. Five males and 5 females were sampled in each group $\left(C, T_{1}\right.$ and $\left.T_{2}\right)$. Blood samples were first taken from 5 males in the control (C) group and from 5 females in the $\left(\mathrm{T}_{2}\right)$ trial group. Then samples were collected from 5 females in the control and from 5 males in $\left(T_{2}\right)$ trial group. Finally, blood samples were taken from 5 males and 5 females in the first $\left(T_{1}\right)$ trial group.They were obtained by the punction of vena cava cranialis and placed in EDTA containing test-tubes. One hour later the following biochemical parameters were analysed: total protein, total lipid, glucose, aspartate aminotransferase (AST) and alanine aminotransferase (ALT). Total plasma proteins were determined by the method of Wolfs on et al.(1948), total fats by the method of Zöllner and Kirsch (1962), glucose by enzymatic colorimetric GOD PAP method after Trinder (1969) with Chronolabe reagents, while AST and ALT were determined according to Zilva (1979), Murray (1984) and Bergmeyer (1983).

The activities of AST and ALT were determined by means of Trace's reagents at $30{ }^{\circ} \mathrm{C}$. The results were processed by standard statistical methods according to Snedecor and Cochran (1967). Mean value (x) and standard deviation (s), were ascertained. The differences between groups were obtained by variance analysis.

Animals employed in this study were maintained in facilities approved by the Croatian Association for Accreditation of Laboratory Animals Care and in accordance with current regulations and standards of the Croatian Ministry of Agriculture.

\section{Results}

Feeding parameters

Mean finishing body mass, average daily gain, average daily food consumption per pig and food conversion (Table 3 ) were calculated after 28 days of trial feeding. Pigs in all groups $\left(C, T_{1}\right.$ and $\left.T_{2}\right)$ had similar mass average $\left(C=24.25 \mathrm{~kg}, T_{1}=24.08 \mathrm{~kg}\right.$ and $\mathrm{T}_{2}=24.18 \mathrm{~kg}$ ). Differences in average finishing body mass were statistically non significant (P> 0.05).

During the trial period (28 days) pigs of the control group (C) had the best average daily gain $(516 \mathrm{~g})$, pigs of the group $\mathrm{T}_{2}$ had somewhat smaller gain $(514 \mathrm{~g})$ while the poorest gain had the pigs of the $T_{1}$ group $(510 \mathrm{~g})$. The ascertained differences in average daily gains were minimal and statistically non-significant $(P>0,05)$.

Average daily feed consumption was the largest (1.038 $\mathrm{g})$ in the control group (C), somewhat smaller $(993 \mathrm{~g})$ in the group $\mathrm{T}_{2}$ and the smallest $(936 \mathrm{~g})$ in the group $\mathrm{T}_{1}$.

Food conversion during the 28 days trial period was highest in the control (C) group $(2.01 \mathrm{~kg} / \mathrm{kg})$, somewhat less in the $T_{2}$ group $(1.93 \mathrm{~kg} / \mathrm{kg})$, and even less in the $T_{1}$ group $(1.84 \mathrm{~kg} / \mathrm{kg})$. 
Table 3

Feeding parameters after 28 days of the trial

\begin{tabular}{|c|c|c|c|c|c|c|c|}
\hline \multicolumn{2}{|l|}{$\begin{array}{l}\text { GROUPS } \\
\text { Additives }\end{array}$} & \multicolumn{2}{|c|}{$\begin{array}{l}\text { C } \\
\text { (controls) } \\
0 \\
\end{array}$} & \multicolumn{2}{|c|}{$\begin{array}{l}\mathrm{T}_{1} \\
\text { Enzyme PLIVA } \\
0.1 \%\end{array}$} & \multicolumn{2}{|c|}{$\begin{array}{l}\mathrm{T}_{2} \\
\text { Kemzyme } \\
0.1 \%\end{array}$} \\
\hline No.of pigs & (n) & 18 & & 18 & & 18 & \\
\hline Stat. data & & $\overline{\mathbf{x}}$ & $\mathrm{s}$ & $\overline{\mathbf{x}}$ & $\mathrm{s}$ & $\overline{\mathbf{x}}$ & $s$ \\
\hline Starting body mass of pigs & $\mathrm{kg}$ & 9.8 & 2.51 & 9.8 & 2.14 & 9.8 & 1.11 \\
\hline Finishing body mass of pigs & $\mathrm{kg}$ & 24.25 & 4.70 & 24.08 & 3.74 & 24.18 & 3.98 \\
\hline Index & $\%$ & 100 & & 99.30 & & 99.71 & \\
\hline Average daily gain per pig & g/day & 516 & & 510 & & 514 & \\
\hline Index & $\%$ & 100 & & 98.84 & & 99.61 & \\
\hline Feed consumption & g/day & 1038 & & 936 & & 993 & \\
\hline Index & $\%$ & 100 & & 90.17 & & 95.66 & \\
\hline Feed conversion & $\mathrm{kg} / \mathrm{kg}$ & 2.01 & & 1.84 & & 1.93 & \\
\hline Index & $\%$ & 100 & & 91.54 & & 96.02 & \\
\hline
\end{tabular}

\section{Biochemical parameters}

On the first trial day the blood plasma protein concentration was significantly higher $(63.15 \mathrm{~g} / \mathrm{l})$ in control group $(\mathrm{C})$ than in the first $\left(\mathrm{T}_{1}=56.23 \mathrm{~g} / \mathrm{l}\right)$ and the second $\left(\mathrm{T}_{2}=\right.$ $=57.42 \mathrm{~g} / \mathrm{l})$ trial groups $(\mathrm{P}<0.05)$, see Table 4 .

Table 4

Concentration of total plasma proteins in pigs $(\mathrm{g} / \mathrm{l})$

\begin{tabular}{|cc|rc|cc|cc|}
\hline $\begin{array}{l}\text { Trial } \\
\text { day }\end{array}$ & Groups & \multicolumn{2}{|c|}{$\mathrm{C}$} & \multicolumn{2}{c|}{$\mathrm{T}_{1}$ (PLIVA) } & \multicolumn{2}{c|}{$\mathrm{T}_{2}$ (Kemzyme) } \\
\hline 1 & $\mathrm{n}$ & $\overline{\mathrm{x}}$ & $\mathrm{s}$ & $\overline{\mathrm{x}}$ & $\mathrm{s}$ & $\overline{\mathbf{x}}$ & $\mathrm{s}$ \\
\hline 14 & 10 & $*, \& 63.15$ & 5.10 & $* 56.23$ & 3.57 & $\& 57.42$ & 3.46 \\
\hline 28 & 10 & 53.96 & 4.98 & 51.48 & 6.13 & 52.00 & 2.43 \\
\hline
\end{tabular}

Legend: ${ }^{*}:{ }^{*}, \&: \&=\mathrm{P}<0.05$ (significant difference among the average values of the control $(\mathrm{C})$ and trial $\left(\mathrm{T}_{1-2}\right)$ groups in three respective trial periods)

Table 5

Concentration of total plasma lipids in pigs $(\mathrm{mmol} / \mathrm{l})$

\begin{tabular}{|cc|cc|cc|cc|}
\hline Trial & Groups & \multicolumn{2}{|c|}{$\mathrm{C}$} & \multicolumn{2}{c|}{$\mathrm{T}_{1}$ (PLIVA) } & \multicolumn{2}{c|}{$\mathrm{T}_{2}$ (Kemzyme) } \\
day & $\mathrm{n}$ & $\overline{\mathrm{x}}$ & $\mathrm{s}$ & $\overline{\mathrm{x}}$ & $\mathrm{s}$ & $\overline{\mathrm{x}}$ & $\mathrm{s}$ \\
\hline 1 & 10 & 2.71 & 0.68 & 2.45 & 0.44 & 2.64 & 0.44 \\
\hline 14 & 10 & 2.77 & 0.37 & $* 2.53$ & 0.26 & $* 3.14$ & 0.69 \\
\hline 28 & 10 & 2.98 & 0.49 & 2.80 & 0.30 & 3.10 & 0.44 \\
\hline
\end{tabular}

Legend: $*^{*}=\mathrm{P}<0.05$ (significant differences among the average values of the first $\left(\mathrm{T}_{1}\right)$ and second $\left(\mathrm{T}_{2}\right)$ trial group in certain trial period)

After the 14th and the 28th day of trial feeding no significant differences in concentration of total blood plasma proteins was found among the control and trial groups $(\mathrm{P}>0.05)$.

No statistically significant differences in concentration of total plasma fat among the control group $(C)$ and the groups $T_{1}$ and $T_{2}$ were observed $(P>0.05)$, see Table 5 . After 14 days of trial, pigs in the group $\mathrm{T}_{2}$ had significantly higher concentration of total plasma fat $(3.14 \mathrm{mmol} / \mathrm{l})$ than pigs in the $\mathrm{T}_{1}$ group $(2.53 \mathrm{mmol} / \mathrm{l})(\mathrm{P}<0.05)$. 
No statistically significant differences in plasma glucose concentration among control (C) and both trial groups $\left(T_{1}, T_{2}\right)$, or between the $T_{1}$ and the $T_{2}$ groups were observed $(P>0.05)$, see Table 6.

No statistically significant differences in plasma AST activity among control (C) and both trial groups $\left(T_{1}, T_{2}\right)$, nor between the $T_{1}$ and the $T_{2}$ groups were established $(P>0.05)$, see Table 7.

No statistically significant differences in plasma ALT activity among controls (C) and groups $T_{1}$ and $T_{2}$ were found $(P>0.05)$, see Table 8. However, on the 14th day of the trial the plasma $A L T$ in the group $T_{1}$ was significantly more active than in the group $T_{2}(P<0.05)$.

Table 6

Plasma glucose concentration in pigs (mmol//)

\begin{tabular}{|cc|cc|cc|cc|}
\hline $\begin{array}{l}\text { Trial } \\
\text { day }\end{array}$ & $\begin{array}{c}\text { Groups } \\
\mathrm{n}\end{array}$ & $\overline{\mathrm{x}}$ & $\mathrm{C}$ & \multicolumn{2}{c|}{$\mathrm{T}_{1}$ (PLIVA) } & \multicolumn{2}{c|}{$\mathrm{T}_{2}$ (Kemzyme) } \\
\hline 1 & 10 & 4.61 & 0.89 & 5.01 & $\mathrm{x}$ & $\mathrm{x}$ & $\mathrm{s}$ \\
\hline 14 & 10 & 4.27 & 4.98 & 4.60 & 0.53 & 5.27 & 0.62 \\
\hline 28 & 10 & 4.96 & 0.68 & 4.98 & 0.37 & 4.77 & 0.58 \\
\hline
\end{tabular}

Legend: $\mathrm{P}>0,05$ (no significant difference among the average values of the control $(\mathrm{C})$ and trial $\left(\mathrm{T}_{1-2}\right)$ groups).

Table 7

Plasma AST activity in pigs (IU/L)

\begin{tabular}{|cc|cc|cc|cc|}
\hline \begin{tabular}{|} 
Trial \\
day
\end{tabular} & Groups & \multicolumn{2}{|c|}{$\mathrm{C}$} & \multicolumn{2}{c|}{$\mathrm{T}_{1}$ (PLIVA) } & \multicolumn{2}{c|}{$\mathrm{T}_{2}$ (Kemzyme) } \\
\hline 1 & $\mathrm{n}$ & $\overline{\mathrm{x}}$ & $\mathrm{s}$ & $\overline{\mathrm{x}}$ & $\mathrm{s}$ & $\overline{\mathrm{x}}$ & $\mathrm{s}$ \\
\hline 14 & 10 & 58.43 & 30.29 & 53.18 & 30.30 & 54.92 & 25.85 \\
\hline 28 & 10 & 56.90 & 21.08 & 54.30 & 23.10 & 41.30 & 20.19 \\
\hline
\end{tabular}

Legend: $\mathrm{P}>0.05$ (no significant difference among the average values of the control $(\mathrm{C})$ and trial $\left(\mathrm{T}_{1-2}\right)$ groups).

Table 8

Plasma ALT activity in pigs (IU/L)

\begin{tabular}{|cc|cc|cc|cr|}
\hline \multirow{2}{*}{$\begin{array}{c}\text { Trial } \\
\text { day }\end{array}$} & Groups & \multicolumn{2}{|c|}{$\mathrm{C}$} & \multicolumn{2}{c|}{$\mathrm{T}_{1}$ (PLIVA) } & \multicolumn{2}{c|}{$\mathrm{T}_{2}$ (Kemzyme) } \\
\hline 1 & 10 & $\mathrm{n}$ & $\mathrm{s}$ & $\overline{\mathrm{x}}$ & $\mathrm{s}$ & $\overline{\mathrm{x}}$ & $\mathrm{s}$ \\
\hline 14 & 10 & 56.38 & 13.69 & 54.94 & 8.10 & 52.15 & 13.73 \\
\hline 28 & 10 & 43.20 & 7.61 & 44.40 & 7.37 & 41.60 & 7.32 \\
\hline
\end{tabular}

Legend: ${ }^{*}{ }^{*}=\mathrm{P}<0.05$ (significant difference among the average values of the first $\left(\mathrm{T}_{1}\right)$ and the second $\left(\mathrm{T}_{2}\right)$ trial group in the respective period).

\section{Discussion}

Feeding parameters

Results of the average finishing body mass data and of the average daily gains show that the multienzyme preparations PLIVA and Kemzyme added to the feed $(0.1 \%$ per starter diet $)$ did not increase either body mass or daily gain in piglets of $9.8 \mathrm{~kg}$ starting body mass compared to control piglets receiving no enzyme additives in the feed.

The results of body mass and of average daily gains in pigs of all the groups are partially in accordance with the same parameters in similar trials of other authors (Crom wel et al. 1988; Adams 1989; Graham et al. 1989), but they differ from the data in some other publications 
(Matoß̌ć-Čajavec et al. 1989; Vinovrški 1990). It is necessary to point out that the addition of Kemzyme had no greater effect on the average finishing body mass nor on the average daily gains than the addition of multienzyme preparation made by PLIVA.

The situation is reverse as for the average daily feed consumption per pig per day in relation to the average finishing body mass and the average daily gain. Pigs of the control group (C) fed the starter without multienzyme additive consumed $10.9 \%$ more food than the pigs of the group $\mathrm{T}_{1}$ fed the same starter to which PLIVA's multienzyme preparation was added, and $4.53 \%$ more feed than the pigs of the group $\mathrm{T}_{2}$ fed the starter with multienzyme additive Kemzyme. Pigs in both groups $\left(T_{1}\right.$ and $\left.T_{2}\right)$ fed mix containing multienzyme additives (PLIVA and Kemzyme) showed similar gains with less feed consumption than the pigs of the control group. Savings of feed in a large pig population contributes considerably to the economy of the swine production. Feed savings were greater when pigs were fed mix with PLIVA's multienzyme preparation added in $\mathrm{T}_{1}$ group. These pigs consumed $8.46 \%$ less feed per $\mathrm{kg}$ gain while the pigs in the $\mathrm{T}_{2}$ group (fed the diet with Kemzyme multienzyme additive) consumed $3.48 \%$ less feed per kg gain compared to control pigs. Nutritional data show that both multienzyme additives considerably influenced the food conversion during the 28 days trial period in pigs weighing from 9.8 to $24 \mathrm{~kg}$. Multienzyme additives improved considerably the food conversion in both trial groups, a finding especially important in feeding period of weaned piglets.

The results we obtained in the food consumption and conversion are in full accordance with the literature data (Graham et al.1989; Matošić-Čajavec et al. 1989,1991; Vinovrški 1990; Böhme 1991) relating to the effect of enzymes in pig production. It can be concluded that multienzyme additive PLIVA and Kemzyme had no influence on finishing body mass and average daily gains in pigs weighing from 9.8 to $24 \mathrm{~kg}$, but they had great effect on average daily food consumption and conversion; the consumption was decreased and the conversion improved.

\section{Biochemical parameters}

Our results indicated that multienzyme feed additives (PLIVA and Kemzyme) do not cause changes in total plasma protein concentration. On the first experimental day, the difference found in plasma protein concentration among the control group $(\mathrm{C})$ and both trial groups $\left(\mathrm{T}_{1}\right.$ and $\left.\mathrm{T}_{2}\right)$ were probably a result of keeping and feeding the pigs in the period prior to the trial (up to $9.8 \mathrm{~kg}$ of body mass). Values of total plasma proteins in pigs of all the groups $\left(C, T_{1}\right.$ and $\left.T_{2}\right)$ during the whole trial period (on the 1st, 14th and 28th day) were very similar to the values of total plasma proteins found in young healthy pigs by Pond et al. (1960), Hoefer et al. (1960), and Swen son (1977) as physiological range; also these are lower than the values found in pigs by Smith et al. (1960) and Rupić (1980), and recommended as physiological limits by Scheunert and Trautmann (1987), previously by Kolb (1962).

Total plasma lipid concentrations in all groups during the trial period were lower than some published values (Rupić 1980; Leman et al.1986) but very similar to other published data (Pond et al. 1960; Swenson 1977). During the experiment, pigs of the group $\mathrm{T}_{2}$ fed the diet with multienzyme additive Kemzyme had a higher concentration of total plasma lipids as compared to pigs of the group $T_{1}$ fed the mix with PLIVA's multienzyme additive. This difference was significant on day 14 , and it could be connected with the composition of multienzyme preparations used in the experiment. PLIVA's multienzyme additive does not contain lipase, while Kemzyme does. Therefore in the intestines of the pigs of the group $T_{1}$ disintegration of consumed lipids and their resorption was possibly poorer. 
Comparable concentration of plasma glucose in pigs of all trial groups $\left(C, T_{1}\right.$ and $\left.T_{2}\right)$ point to the fact that multienzyme feed additives PLIVA and Kemzyme had no effect on the plasma glucose concentration during the feeding period from 9.8 to $24 \mathrm{~kg}$ body mass. Plasma glucose concentrations in all groups were lower than values found by Leman et al. (1986), they were within the physiological standards for pigs (S wen son 1977; Scheunert and Trautmann 1987), i.e. slightly over the standards mentioned by Kolb (1962).

Furthermore, no significant differences in the activity of plasma AST were found among pigs in both the control (C) and groups $T_{1}$ and $T_{2}$. This indicates that multienzyme feed additives PLIVA and Kemzyme had no influence on the AST activity. No acute cases of liver damage or myopathy were thus observed.

Comparable plasma ALT activities in pigs of the control and trial groups point to the fact that multienzyme feed additives PLIVA and Kemzyme did not affect the plasma ALT activity, hence no dietetic hepatosis, other acute or chronic hepatopathies or other liver damage were caused by these substances (Cornelius et al. 1959; Orstadius et al. 1959; Forenbacher 1972). The AST and ALT plasma values in pigs of all 3 groups in experiment, throughout the complete experimental period were higher than those published by others (Gürtler and Richter 1959; Žurić and Stanković 1991), probably because we analyzed the samples at $30^{\circ} \mathrm{C}$, i.e. at a temperature higher than the above mentioned authors. On the basis of our results it can be concluded that multienzyme feed additives PLIVA and Kemzyme at a dose rate of $0.1 \%$ have no adverse effects in growing pigs.

\section{Vliv multienzymových preparátů na produkci a vybrané biochemické ukazatele v krevní plazmě selat od 10 to 24 kg živé hmotnosti}

Vliv multienzymových preparátů PLIVA a Kemzyme na růst a vybrané biochemické ukazatele byl sledován na 54 selatech plemen Yorkshire a švédská landrace v pokusu trvajícím 28 dnů. Živá hmotnost selat v pokusném období vzrostla z $9.8 \mathrm{na} 24 \mathrm{~kg}$.

Kontrolní skupina $(C)$ byla krmena dietou bez prídavku aditív $(n=18)$, skupina $T_{1}$ dostávala multienzymový preparát firmy Pliva $(n=18)$, a skupina $T_{2}(n=18)$ preparát Kemzyme, a to v dávkách $0.1 \%$. V každé skupině bylo 9 kanečkủ a 9 prasniček. Selata byla odchovávána $v$ boxech a krmena a napájena ad libitum. Nutriční parametry byly sledovány na konci pokusu, vzorky krve $\mathrm{k}$ biochemickým vyšetřením byly odebírány 1., 14. a 28. dne pokusu. Přirústky hmotnosti byly ve všech 3 skupinách podobné. Kontrolní skupina zkonzumovala o $10,9 \%$ víc krmné směsi než skupina $T_{1}$ a $04,53 \%$ více než skupina $T_{2}$. Obe pokusné skupiny však vykazovaly lepší konverzi krmiva než skupina kontrolní. Biochemickými analýzami nebylo zjištěno narušení zdravotního stavu zvírat.

\section{References}

ADAMS, C. A. 1989: Kemzyme i probava stočne hrane. Krmiva 31:139-144

BERGMEYER, H.U. 1983: Methods of Enzymatic Analysis. 3rd ed. Verlag Chemie, Weinheim-Deerfield Beach Florida-Basel. pp. 26-72

BÖHME, H. 1991: Effect of enzyme supplements for growing pigs. Nutr. Abstr. Rew. (Series B) 61:984

CORNELIUS, C. E. , BISHOP, J., SWITZER, J., RHODE, E. A. 1959: Serum and tissue transaminase activities in domestic animals. Cornell Vet. 49:116-126

CROMWEL, G. L., CANTOR, A. H., STAHLY, T. S., RANDOLPH, J. H. 1988: Efficacy of betaglucanase addition to barley-based diets on performance of weaning and growing finishing pigs and broiler chicks. J. Anim. Sci. 66 (Suppl.1):46

DIERICK, N. A. 1989: Biotechnology aids to improve feed and feed digestion. Enzymes and fermentation. Arch. Anim. Nutr. 39:241-261

FORENBACHER, S. 1972 : Eksperimentalni i klinicki prilozi dijagnostičkom značenju serumskih transaminaza kod životinja. Vet. arhiv 42:171-208 
GRAHAM, H., FADEL, J. G., NEWMAN, C. W. 1989: Effect of pelleting and beta-glucanase supplementation on the ileal and fecal digestibility of a barley-based diet in the pig. J. Anim. Sci. 67:1293-1298

GÜRTLER, H., RICHTER, H. 1959: Zur Kenntnis der Transaminasen im Serum von Pferd, Rind und Schwein. Zbl. Vet. Med. 6:705-713

HOEFER, J. A., MILLER, E. R., ULLREY, D. E., RITCHE, H. D., LUECKE, R.W. 1960: Interrelationship between calcium, zinc, iron and copper in swine feeding. J. Anim. Sci. 19:249-259

INBORR, J. 1989: Enzymes in combination. Feed International:16-27

KOLB, E. 1962: Lehrbuch der Physiologie der Haustiere. VEB Gustav Fischer Verlag, Jena. pp. 388-405

LEMAN, A. D., STRAW, B., GLOCK, R. D., MENGELING, W. L., PENNY, R. H. C., SCHOLL, E. 1986: Diseases of Swine. Iowa Univesity Press, Ames, pp. 26-68

MATOŚIĆ-ČAJAVEC, V., MIKAČIC, D., VRANA, M., GAAL, E., KRSMANOVIĆ, M., MARKOVIĆ, I., MARKOVIĆ-DEVČIĆ, B. 1991: Enzymes in pig nutrition. Praxis vet. 39:113-117

MATOŠIĆ-ČAJAVEC, V., VRANA, M., MIKAČIĆ, D., KRSMANOVIĆ, M. 1989: Investigation of stimulative effect of alkaline protease in the nutrition of piglets after weaning. Praxis vet. 37:189-193

MURRAY, R. L. 1984: Clinical Chemistry. Theory, analysis and correlation. Kaplan, L.A., Pesce, A.J. ( Eds.). Mosby, St. Louis, p. 1090 and pp.1105-1108

ORSTADIUS, K., WRETLIND, B., LINDBERG, P., NORDSTRÖM, G., LENNEK, N. 1959: Plasma transaminase and transferase activities in pigs affected with muscular and liver dystrophy. Zbl. Vet. Med. A.: 971-989

POND, W. G., KWONG, E., LOOSLI, J. K. 1960: Effect of level of dietary fat, pantothenic acid and protein on performance of growing fattening swine. J. Anim. Sci. 19: 1115-1123

ROTTER, B. A., MARQUARDT, R. R., GUNTER, W. 1990: Optimising response from enzymes in poultry and pigs diets: New methods for measuring response. In: T. P. Lyos ( Ed. ), Biotechnology in the Feed Industry, Alltech Technical Publications, Nicholasville, Kentucky, pp. 149-159.

RUPIC, V. 1980: Prilog poznavanju utjecaja bakarnog sulfata obroka na ukupne masti, ukupne bjelančevine i frakcije bjelančevina krvne plazme tovnih svinja. Agronomski glasnik 62:441-451

SCHEUNERT, A., TRAUTMANN, A. 1987: Lehrbuch der Veterinär-Physiologie. 7. Aufl. Paul Parey, Berlin und Hamburg, pp. $84-85$ and pp. 160-207

SMITH, I. D., HOEKSTAR, W. G., GRUMMER, R. H., PHILLIPS, P. H. 1960: Studies on serum proteins of normal and parakeratotic pigs. J. Anim. Sci. 19:580-589

SNEDECOR, G., COCHRAN, W. G.1967: Statistical Methods.Iowa University Press, Ames

SWENSON, M. J. 1977: Duke's Physiology of Domestic Animals. 9th ed. Cornell University Press, Ithaca and London, pp. 21-61

TRINDER, P. 1969: Determination of Blood Glucose using 4-Aminophenazone. J. Clin. Pathol. 22:246-248

VINOVRSKI, Z. 1990: Problems in piglets nutrition. Praxis vet. 38:131-135

WOLFSON, W.Q., COHN, C., CALVARY, C., ICHIBA, F. 1948: Studies in serum proteins. Rapid procedure for estimation of total proteins, true albumin, total globulin, alpha globulin, beta globulin and gamma globulin, in $1.0 \mathrm{ml}$ of serum. Am. J. Clin. Path. 18:723-730

ZILVA, J. F., PANNEL, P. R. 1979: Clinical Chemistry in Diagnosis and Treatment. Loyd-Luke, London, pp. 338-339

ZÖLLNER, N., KIRSCH, K. 1962: Über die quantitative Bestimmung von Lipoiden (Mikromethode) mittels der vielen natürlichen Lipoiden (alle bekannten Plasmalipoiden) gemeinsamen Sulfophosphovanilin-Reaktion. Z. ges. exp. Med. 135:546-561

ŽURIĆ, M., STANKOVIĆ, H. 1991: AST, ALT and GGT activity in the blood serum of intensive breeding pigs in relation to pathohistological liver problems. Vet. stanica 22:195-204 